M.B. Komlenic,

N.M. Milicevic*, M.B. Milenovic

\title{
Application of behavioral theory in music
}

\author{
State University of Nis \\ Cirila i Metodija 2, Nis, 18000, Serbia \\ nesa2206@gmail.com*
}

Received on September 29, 2020; accepted on December 10, 2020; published on December 31, 2020

\begin{abstract}
This paper presents an explanation of some laws of perception with regard to $\mathrm{S}-\mathrm{R}$ principles of learning psychology. The possibility of connecting two great schools in the science of psychology - behaviorism and gestalt psychology - which are often presented as opposites, is demonstrated and, by this is also described an analogous model of Gestalt theory within behavioral principles, providing insight into the partial equivalence of the two theories, where the essence of the analogy is the claim of the existence of identical or very similar explanations in the two theories, only with different formulated constructs. The authors prove that these are different terms, and the same or similar concepts: what are sensations and perceptions in gestalt psychology, are molecular and molar stimuli in behaviorist psychology. A set or assembly of smaller, elementary (molecular) stimuli gives a molar stimulus that causes the evocation of the main perceptual reaction, which is analogous to the law of formation of stimuli in observations in Gestalt psychology. Authors demonstrate the explanatory potential of behavioral theories in the field of music, i.e. the phenomenon of melody transposition, the famous argument of gestaltists. An important construct in the work is external inhibition, as well as intervals - interruptions, spaces - between stimuli, because they also represent stimuli that participate in the construction of the whole, ie. there is no empty space and empty space is a kind of stimulus.
\end{abstract}

Keywords:stimulus; external inhibition; melody transposition; gestalt.

Information for citation: Komlenic M.B., Milicevic N.M., Milenovic M.B. (2020), "Application of behavioral theory in music", Research Result. Pedagogy and Psychology of Education, 6 (4), 96-105. DOI: 10.18413/2313-8971-2020-6-4-0-8.

\section{Комленич М.Б., Миличевич Н.М.*, Миленович М.Б. \\ Применение теорий обучения в музыке \\ Философский факультет Университета в Нише \\ ул. Кирилла и Мефодия, 2, Ниш, 18000, Республика Сербия nesa2206@gmail.com*}

Статья поступила 29 сентября 2020; принята 10 декабря 2020; опубликована 31 декабря 2020 
Аннотация. В работе предлагается объяснение некоторых закономерностей восприятия психологии обучения принципами S-R. Авторами указаны возможности соединения двух великих школ в психологической науке - бихевиоризма и гештальтпсихологии, - которые часто воспринимаются противоположными. Описана аналогическая модель гештальт теории в рамках бихевиористических принципов, что позволяет обнаружить частичную эквивалентность двух теоретических подходов. Аналогия проявляется в утверждении о существовании тождественных или очень подобных объяснений в двух теориях, только выполненных при помощи разных элементов. Авторы доказывают, что речь идет о разных терминах, но тождественных или подобных понятиях: то, что является восприятием образа и формы в гештальтпсихологии, соответствует молекулярным и молярным стимулами в бихевиористической. Набор или состав более мелких, элементарных (молекулярных) стимулов дает молярный стимул, вызывающий основные реакции восприятия, что соответствует закону формирования стимулов в восприятии в гештальтпсихологии. Значение работы заключается в проявлении пояснительных возможностей бихевиоральных теорий, в том числе, и в области музыки, то есть, по отношению к феномену транспозиции мелодии (знаменитый аргумент стороников теории гештальта до сегодняшнего дня). Важным элементом работы является внешнее ингибирование, а также интервалы - перерывы, пространства между стимулами, так как они представляют собой стимулы, участвующие в создании целого, то есть, нет пустоты, так как пустота становится своеобразным стимулом.

Ключевые слова: стимул; внешнее ингибирование; транспозиция мелодии; гештальт.

Информация для цитирования: Комленич М.Б., Миличевич Н.М., Миленович М.Б. Применение теорий обучения в музыке // Научный результат. Педагогика и психология образования. 2020. Т.6. №4. С. 96-105, DOI: 10.18413/2313-89712020-6-4-0-8.

Introduction. Traditionally, the science of psychology considers that the school or direction of Gestalt psychology is not only the most deserving for the explanation and development of the psychology of perception, but perhaps the only one to which this fundamental cognitive process can belong (Komlenic, 1997; Krech, Crutchfield, \& Livson, 1974; Murphy, 1949). At the same time, it is neglected that learning psychology, not only modern, with a rather enviable level of achievement, but also traditional associationist $\mathrm{S}-\mathrm{R}$ learning psychology, under the auspices of a very influential direction of behaviorism at the beginning and middle of the last century, dealt with some processes and laws of perception (Allport, 1955; Boring, 1942; Hilgard and Bower, 1975, Radonjic, 1985).
Thus, postulate 11, of Hull's hypothetical-deductive theory of learning and behavior (Hull, 1943, 1952) is an attitude or law that refers to perception and is called external inhibition (afferent interaction of stimuli in external inhibition):"All afferent nerve impulses (s), which are active in the nervous system at any given moment, act on each other, so that each changes into something that is partially different $(\breve{s})$, depending on each existing nerve impulse at the same time or a combination of such impulses" (Osgood, 1953: 361)

A very fruitful attitude, which enables, on the one hand, the approximation of S- R and gestalt psychology, and on the other hand, the clarification of many phenomena within the S$\mathrm{R}$ point of view itself.

In explaining humor, for example (Komlenic, 2013), it is the golden key to a bet- 
ter understanding of some problematic phenomena, such as black humour, the effect of a joke and when we are not in the mood, laughter at the expense of a friend (without betraying a friend), a joke at one's own expense, etc., but it also has its explanatory power in poetry, prose, aphorisms and verbal expression in general (Komlenic, 2014). Hull expressed this postulate of interaction in 1943 not so clearly (as Postulate 2 - then that postulate had the ordinal number 2, and later 11), and more done according to feeling than systematically. Namely, the statement is rather vague, so that each changes into something that is partially different. In his book from 1952, he derives a clearer definition of the same:

"When the reaction is conditioned on a stimulus $\left(\mathrm{S}_{1}\right)$, and one or more neutral stimuli $\left(S_{2}, S_{3} \ldots\right)$ are present with $S_{1}$, the afferent impulses from that combination produce a new molar impulse ( $\breve{\mathrm{s}})$. This new impulse is equivalent to the stimulus to a greater or lesser extent, depending on the distance from $S_{1}$ on the qualitative continuum. The resulting generalized reaction potential at $\breve{s}$ ( $\breve{s} E r)$ will be less than that at $\mathrm{S}_{1}$ (sEr), depending on the distance from each other" (Hull, 1952: 11)

(The farther they are, the more the reaction to $S_{1}$ will retain its authenticity -author's note).

Hull also gives an equation that shows the amount of reduction of the reaction potential under the following conditions (Osgood, 1952):

$$
\mathrm{d}=\frac{\log \frac{s E r}{\check{s} E r}}{j}
$$

wherein:

$\mathbf{d}$ :amount of difference, i.e. reduction of $\mathrm{sEr}$ in JND units (just noticeable differences) sEr: original reaction potential (to stimulus $S_{1}$ ) šEr: reaction potential reduced by external inhibition due to the presence of additional (interfering) stimuli

$\mathbf{j}$ : constant determined by the shape of the generalization gradient ( $j$ is larger if the gradient is less steep, i.e. if it is plateau-curtic, where the amount $d$ will be smaller).
Problem and goal. One of the basic problems and goals of this paper is to find ways to simplify these and similar formulas to a simpler and more understandable level (theoretical goal), and to demonstrate their use and application on a practical level (empirical problem and goal), above all - in this paper at least - verbal and musical.

First, we point out and note that we (Radonjic, 1985; Komlenic, 2011, 2013), in addition to reactive (Ir) and conditional (sIr), also met external inhibition (Ie).

Most consistently, Ie is a component of the $\mathrm{V}$ - variable, the dynamic intensity of the stimulus (Komlenic, 2003). It reduces the dynamic intensity $\left(\mathrm{V}_{1}\right)$ of the original stimulus $\left(S_{1}\right)$ in the exposed set of stimuli from the middle $\left(S_{1}, S_{2}, S_{3} \ldots\right)$. Obviously, the power of Ie opposes the power of generalization and tends to discriminate. That is, in contrast to the tendency to perform a generalized reaction, i.e.lurks to trigger a discriminatory reaction, with greater or lesser force, depending on the distance on the continuum, i.e. lowering the degree of similarity of the stimulus. Ie is an inhibitor, stronger or weaker, of the reaction in execution. The variable is almost identical to conditional inhibition - which is a sign of entropy, redundancy of the Hall system. Otherwise, it can be noticed that the term Ie is similar to the associative inhibition, which Osgood (1952, 1963) speaks about.

Not completely mathematically equivalent, but quite satisfactory, formula can be simplified in several ways, bearing in mind that external inhibition actually refers to the reduction of the reaction potential to stimulus $S_{1}$ due to the presence of other stimuli $\left(\mathrm{S}_{2}, \mathrm{~S}_{3}\right.$..) that pull their side, that is, they activate the reaction potential of another, theirown reaction (Nagge, 1935). For example, the formula:

$$
\mathrm{s} \overline{\mathrm{E}} \mathrm{r}=\mathrm{s}_{1} \mathrm{Er}-\breve{\mathrm{s}} \mathrm{Er}
$$

represents a simplification of the previous one and says that the effective reaction potential ( $\mathrm{s} \overline{\mathrm{E}} \mathrm{r}$ ) will be the result of the difference of the reaction potential to a certain stimulus $\left(S_{1}\right)$ and another reaction potential, which initiate

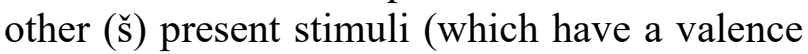
of another reaction, say $R_{2}$ ). 
The equation can also be

$$
\mathrm{s} \overline{\mathrm{E}} \mathrm{r}=\mathrm{s}_{1} \mathrm{Er}-\mathrm{s}_{2} \mathrm{Er}
$$

wheres ${ }_{2}$ Eris the tendency of some other reaction (non- $\left.\mathrm{s}_{1} \mathrm{Er}\right)$ due to the presence of the stimulus $S_{2}$. If $s_{1} E r$ is greater than $s_{2} E r, R_{1}$ will be evoked, and for $S_{2}$ in that case we can say, for example, that it has a subdynamic intensity. And vice versa, if $s_{2}$ Erprevails, $S_{2}$ will have dynamic intensity, and $\mathrm{S}_{1}$ subdynamical.

Or, the simplest and clearest formula, which we will stick to:

$\mathrm{s} \overline{\mathrm{E}} \mathrm{r}=\mathrm{S}_{1}-\mathrm{S}_{2}=\mathrm{V}_{1}-\mathrm{V}_{2}$, which simply means (Komlenic, 2003):

The success of the perception of exposed (Woodworth, 1954) or exposed $S_{1}$ stimuli depends on the competition (competition, interference) of other $S_{2}$ stimuli - exposed now, but also in previous experience, without current $S_{2}$ exposure! - that is, from the dominance of the dynamic intensity of the stimulus $\mathrm{S}_{1}\left(\mathrm{~V}_{1}\right)$ over the dynamic intensity $\mathrm{S}_{2}\left(\mathrm{~V}_{2}\right)$.

Main Part. As we said that there are only 30 letters in the verbal medium, and many words, which is a very fertile ground for the action of external inhibition, we can conditionally say that the situation is even worse for music: for many different melodies that exist, we have only 8 notes! One of the aims of this paper is to demonstrate the power of external inhibition and perception of similarity in both musical stimuli, which neither behaviorists nor gestaltistsdid in such a form.

\section{Gestalt and $S-R$ approach}

Gestalt is a German word that means form, shape, structure, whole. The founders of this school are Max Vertheimer (1880-1943), Kurt Koffka (1886-1941) and Wolvgang Köhler (1887-1967). Their motto was the whole is more than the sum of their parts. The whole experience is what a person is first and foremost directly aware of.

Afterwards, it can onlybe artificially disassembled into elements (Fajgelj,2014).Gestaltists went so far as to advocate a nativist view and argued that this ability to perceive the whole was innate, independent of experience (Kofka, 1935; Kohler, 1929).

It began with the philosopher, Christian von Ehrenfels (Krech and Crutchfield, 1974;
Murphy, 1949; Milicevic, 2019), who published his observations on perception in the late 19th century. Ehrenfels may have laid the very foundations of this view (Gestalt psychology and field theory) by citing examples of melody transposition. Namely, one melody is perceived as the same when played from $\mathrm{d}$ minor and from a minor. The elements, the tones, represent completely different stimuli, and the whole remains the same. The whole dominates the parts. (It has a stronger dynamic intensity of stimuli! - We start with a battle, that is, with cooperation).

Perhaps most precisely, Gestalt psychologists have criticized the $\mathrm{S}-\mathrm{R}$ approach (response to stimuli) by remarking that one does not react to stimuli as such, but to relations, relations between stimuli (Jones and Elcock, 2001). In other words, the stimulus does not represent the absolute that provokes the reaction, but the whole of perception is important for the perceptual experience.

The advocates of $\mathrm{S}-\mathrm{R}$ are accused of breaking the whole into elements, which is impermissible, because the stimulusis nothing, one whole is perceived as such even when the stimuli are completely different, and in the same arrangement. For example, the letter $\mathrm{T}$ remains that letter even when it is made up of different constituent elements, and even elements in the form of other letters:

$\mathrm{m} \mathrm{m} \mathrm{m} \mathrm{m}$

$\mathrm{m}$

$\mathrm{m}$

$\mathrm{m}$

We do not perceive the exposed stimuli as a set of lowercase letters $\mathrm{m}$, but as a capital letter $\mathrm{T}$.

A large number of stimuli constantly act on our senses. Namely, we never experience only colours or lights or certain tones and noises, but we always perceive objects as well: the street, the truck, the table, the pencil. Perceptions are always complete.

Gestalt division into stimuli and perceptions is relative and adequate to the division of stimuli into molecular and molar, because what in one case is perception (group of stimuli), in another is only part of an even larger set, i.e. 
simple stimulus and vice versa: the smallest and most imperceptible stimulus in a certain situation can very well represent a very large and important perception.

For example, the letter $\mathrm{H}$ is as simple a stimulus as the letter in the word Horoscope (we do not react to $\mathrm{H}$, but to the word), while it is complex on a traffic sign, when it means hospital. It is composed of dashes (-), but we do not react to the dashes, but to the whole of perception: in this case $\mathrm{H}$ is a whole that means a hospital nearby - and we can consider the whole as an even larger set: $H$ - so the hospital is nearby-you should drive slower and make no noise. We react to a dash, for example, when it represents the letter $I$, etc.

One melody, for example, which gestaltists hold so much as an essential whole, can also be unnoticed as a whole, but only as an element of complete perception (concert, mix of songs, musical mix, festival, musical direction, etc.). In contrast, a single tone can be a complete perception (when a piano tuner, for example, combines the vibrations of a string more molecular stimuli - into the required note, which is a very difficult, professional and not so short - lived job, but molar, large!). It all depends on the effect, on the reinforcement, i.e. on the place between the stimuli where the reinforcement islocated (with piano tuner it is placed after a single note!) And where the reinforcement will be placed, i.e. where the elements are rounded as a whole, depends on previous experience. but also from the current goal or motive, for example: if I am the organizer of a three-day music festival, then the three-day event is a whole for me, and the participants, their songs, their performance dates, etc. are elements; if I am a participant in a festival where I perform with three songs, then my important whole begins with the first note of the first melody with which I perform and ends with the last note of the third...

So, the gestalt notion of the whole is imprecise and indefinite, because there is no whole in itself - we always consider the whole as a definite, very limited set of stimuli (otherwise the whole should be the whole universe...?) - and that limitation of the set of stimuli - here is behavioral theory it seems more precise - it takes place where the effect is - reward, reinforcement - in general, the informative value of the stimulus, which is important for that particular moment, i.e. a certain situation or motive at that moment, based on previous experience and acquired habits.

And one always reacts to both the part and the whole, only - depending on the effect depending on where the effect is, sometimes more intensely on the part, and sometimes on the whole.

There is, therefore, a dialectical development of stimuli and perception, with a transition to a new quality.

It seems that the incomprehensibility of the approach to the problem of delimitation of part and whole is the main cause of(unnecessary) misunderstanding of two points of view, and that it can be said that the organism reacts to both part and whole, depending on the dominance of one or the other (Komlenic, 2003), which still depends on the dynamic intensity of the stimulus (part or whole), and this is a function ofboth the intensity of external stimuli (S) and internal factors, primarily learned habits ( $\mathrm{sHr}$ ), and to which the reward is closely related - reinforcement.

Therefore, it is understandably more probable to react to the whole, because the whole, as a larger stimulus, simply more often represents a physically stronger stimulus $(\mathrm{S})$, and its dynamic intensity (V) will be mostly higher.

Let us underline the principles or arguments of the behaviorist $\mathrm{S}-\mathrm{R}$ theory of learning and behavior relevant to the analysis and solution of the problems we deal with here:

- For perception, elements (part, molecular) and whole (gestalt, molar) are also important. Which of these two will be dominant depends on previous learned habits and current motives.

- And the intervals - interruptions, spaces - between the elements are the elements(a kind of stimuli)

- To perceive the similarity of two or more perceptions, a quantum of identical elements (or stimuli, or intervals between stimuli, 
or both) is necessary. Identity of elements is a necessary condition for the perception of similarity of wholes: the principle of generalization and generalized strength of habit (Hull, 1952; Osgood, 1953; Radonjic, 1981).

- The construct of S-R psychology, denoted by the term external inhibition, is an important factor in the perception of similarity, because it acts in the direction of perception of something else $\left(\mathrm{S}_{2}\right)$ in addition to the exposed $\left(\mathrm{S}_{1}\right)$, and this often happens due to similarity of $\mathrm{S}_{1}$ and $\mathrm{S}_{2}$.

Methodology and methods. The work deals with the theoretical analysis of the principles of seemingly incompatible psychological schools: behavioral and gestalt psychology.
Some kind of content analysis was used in the paper. The similarities and differences of one composition transposed in three different ways (Vltava) and the other composition (Yesterday) were analyzed, as well as the similarities and differences between two seemingly similar compositions (Black butterfly and Shoshana).

\section{Melody transposition}

Let us also look at the application of the above $S-R$ principles to the perception of the similarity of melodies, which gestaltists have often, for decades already - mostly called melody transposition - cited as an argument for their theory and a counter-argument for behaviorist.

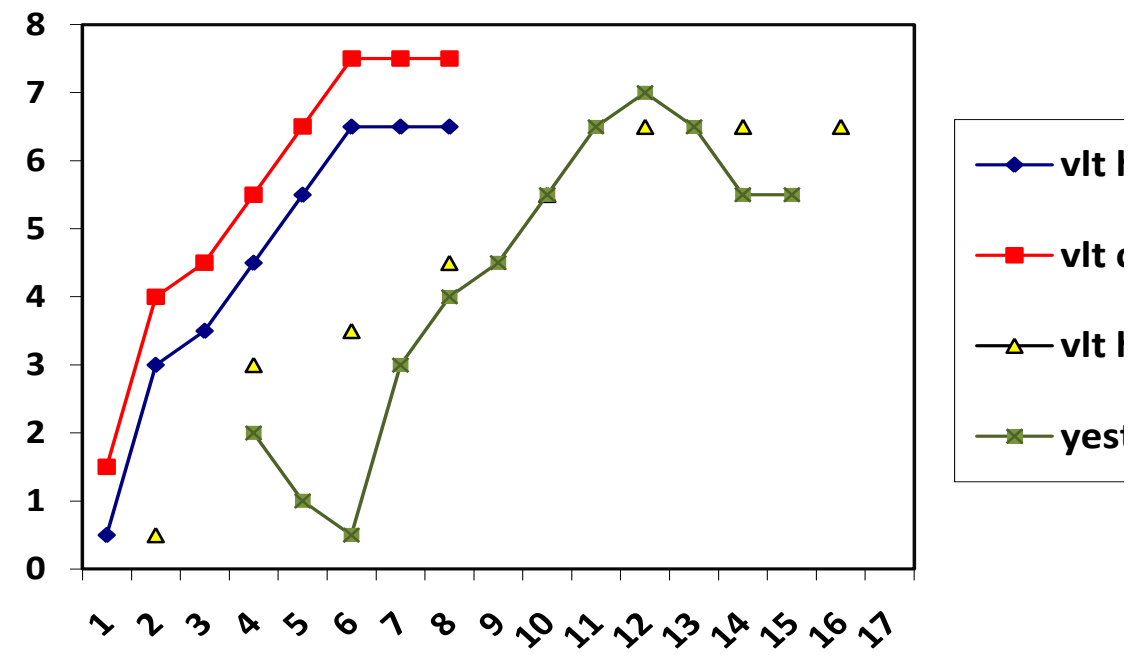

Fig.1 Beginning of the "Vltava" melody in three ways and the "Yesterday" melody Рис.1 Начало мелодии «Влтава» (англ. "Vltava") тремя способами, а также мелодии «Вчера» (“Yesterday”)

On the horizontal axis are time intervals (approximately - seconds), while on the ordinate (vertical axis) are numbers that indicate the height of the notes, and notes are marked by dots on the lines. On the ordinate (vertical axis) are whole pitch intervals between notes -spaces between digits: approximately, but without a significant loss in accuracy in relation to the representation in the notation system, number 1 on the ordinate is note c, on 0.5 is $\mathrm{h}, 1.5$ is cis, 2 is $\mathrm{d}, 3$ is e, on 3,5 should be $\mathrm{f}, 4,5=\mathrm{g}, 5,5=$ a, $6,5=\mathrm{h}, 7=\mathrm{c}$ and $7,5=$ cis. The closed-blue line (second from the left) shows the beginning of the Vltavaby Bedřich Smetana played from $\mathrm{h}$,the red (first left) line shows the same melody from cis, yellow -the same Vltava from h (as well as closed-blue second line left), only in slower rhythm - twice slower -two seconds space between two adjacent tones and, finally, green line (far right) marks the opening tones of the Beatles' Yesterday song.

What do we see on the chart - what can we conclude? - We see that the two lines on the left side are very similar in shape (whole, gestalt), and they have completely different notes - the heights of the points, the numbers 
on which the points of connection of the lines are. They are a pictorial representation of a famous concept: the transposition of a melody. Why are they similar if their elements- notes are different? Precisely because, as we can see in the picture, notes (numbers) are not the only elements - the only stimuli- that make up the whole. Namely, these are also the intervals (here in height) between the elements - notes: two lines have equal intervals, arranged in the same structure! That is why they form very similar images! So the elements are not so different - as the Gestaltists claim - there are identical elements indeed.

Yellow markers also demonstrate rhythm (speed of sequence of elements, i.e. notes) as an important stimulus for perception: the same notes as on the closed-blue line (second from the left) - it is Vltava from note $h$ in both - the same pitch (vertical) intervals, but the images are already quite distant from each other in terms of similarity (yellow is larger, more stretched ..), because the time intervals (horizontally) are not the same. It is as if the yellow curve is the most different from all the others even the line for Yesterday (all the way to the right) seems to be more similar to the two on the left than the yellow one? - However, every connoisseur of these two melodies will already guess from the first few notes of the Vltava played slowly (yellow, the second from the right) that it is the Vltava, and not Yesterday!

The initial stimuli of the melody Yesterday (line 4, far right) are shown to demonstrate an attitude complementary to the one discussed so far: the identity of the elements (note here) is not sufficient for the perception of similarity, if there is strong external inhibition of other elements (intervals). Namely, most of the notes are the same as in the Vltava (especially the Vltava from cis - closed blue, the other from the left), i.e. the positions of the points mostly coincide in height on these two lines, and the picture is completely different, which indirectly supports the gestaltist attitudes, but also directly - behavioral ones.

We will look at another musical example of the analysis of the similarities and differences between the whole and the elements.

Identical elements (notes), but with different wholes (melodies):
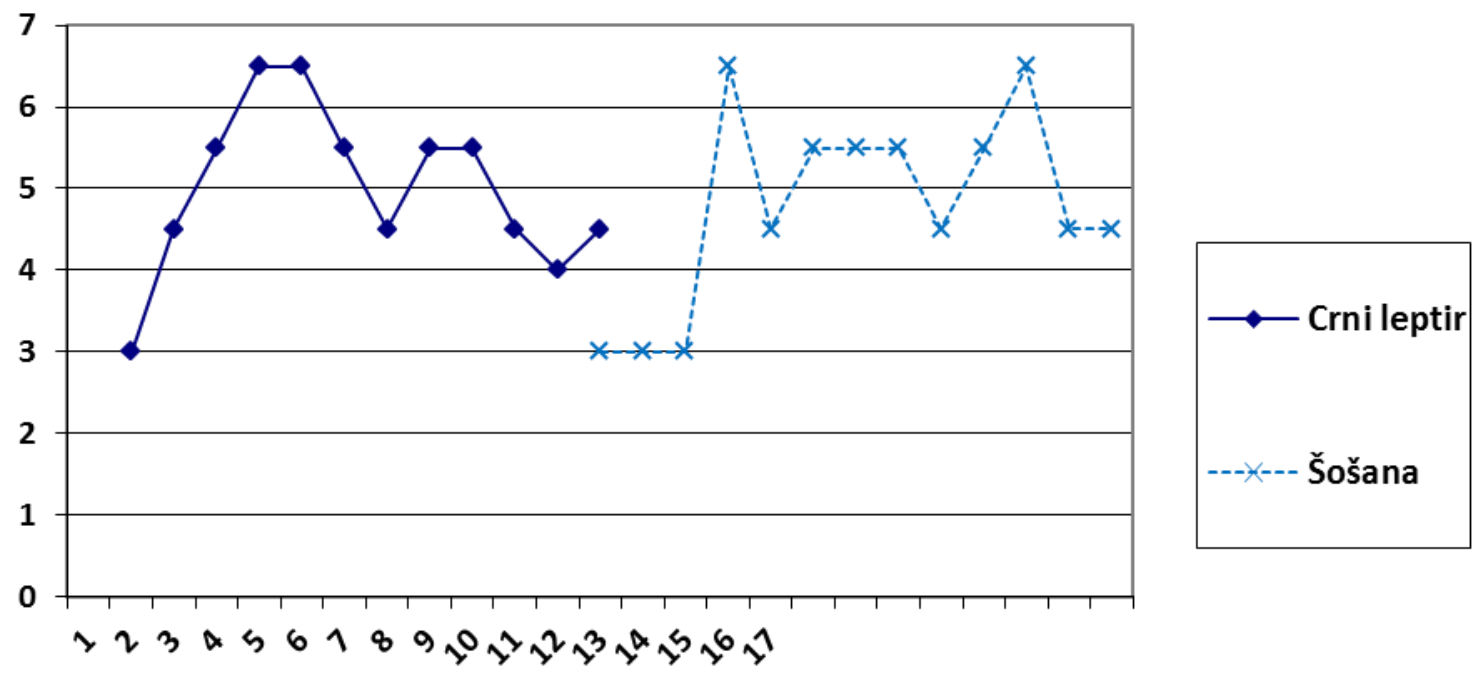

Fig. 2 The beginning of the melody "Black Butterfly" and the melody of "Shoshana" Рис. 2 Начало мелодии «Черные бабочки» (серб.«Црнилептир») и мелодии Шошана

This graph (Fig. 2) demonstrates the identity of the elements (exactly the same notes participate) and the diversity of wholes (melodies completely different). However - having 
in mind the considerable scope of the analysis of Figure 1 - here we will only ask a question, leaving the analysis to the reader: do the gestalts (wholes, molarities) really differ so much: don't the two lines seem to be-as much as, if not quite - similar? So, never neglect the elements, they are very important. Auditively observed only - listen to the above melodies there is no similarity between the Black Butterfly(YU Grupa, 1973) and Shoshana(Zlatko \& DAH, 1976), as opposed to the visual similarity of the elements and the whole ?!- Why? - Because - according to the exposed S - R theory at least - in the perception of music, it seems that the intervals between the notes have a stronger dynamic intensity of the notes itself.

Discussion and conclusion. Just as there is inhibition of the reaction (reactive), so there is inhibition of the observed stimulus (external inhibition - although, analogously to reactive, it would be more correct to call it-stimulus inhibition).

Since in practice the $\mathrm{S}-\mathrm{R}$ bond is almost never created to one pure and isolated, the stimulus $\operatorname{itself}\left(\mathrm{s}_{1}\right)$, but it is always given in the presence and combination with other stimuli $(\breve{\mathrm{s}})$, and, whether and in what intensity a certain reaction will take place $\left(\mathrm{R}_{1}\right)$ will depend on the present rivalcombination of stimuli, and on its centrifugal force to initiate another reaction $\left(\mathrm{R}_{2}\right)$.With this postulate, Hull implicitly, at least, extended a hand of reconciliation to gestalt psychology, and the author of this paper tried to inform it concretely, that is, explicitly. Namely, the stimuli needed to provoke a reaction $\left(\mathrm{R}_{1}\right)$ can be grouped by cohesive forces (centripetal) into a set of stimuli $\left(\mathrm{S}_{1}\right)$ according to the principle of touch, similarity and some others (internal potential, internal excitation). The same forces squat, lurk, vibrate, resonate around $\mathrm{S}_{1}$ (due to competition of what has been learned, i.e. interference) and tend to adhere, making the centrifugal valence to perform $\mathrm{R}_{2}$ (the phenomenon of external inhibition).

Whether the latter will happen depends on the strength of the reaction potential of $R_{2}$, and this largely depends on the dominance of $S_{2}$ over $S_{1}$, achieved on the basis of the strength of the earlier grouping of some stimulus ele- ments from $S_{1}$ to stimulus $S_{2}$, and thanks, most often, to reinforced habit. Thus, we combine the $\mathrm{S}-\mathrm{R}$ and Gestalt approach with a compromise: Gestalt laws exist at the operational (empirical, descriptive, phenomenological) level, but: they are neither innate, as Gestalt theory mostly advocates (but the results of previous experience, learning), nor do they represent a principally-theoretically special type of connection and selection of stimuli and reactions (they are yet reducible to the principle of touch and similarity).

So, the strength of the previous association is responsible for the current grouping, not the other way around! This line of thinking was initiated by others, such as Pavlov (1927).

Much more can be said about the gestaltlaws of perception, and about some of the shortcomings of that naive-holistic approach, especially about the bringing of gestalt explanations under associative $\mathrm{S}-\mathrm{R}$ principles. The focus from which the main explanation develops is to emphasize the importance of habit in the process of perception, generalized forceof habit, i.e. the process of generalization of stimuli, and dynamic intensity of stimuli (Hall term - variable V).

Significant is the effect (which in fact is a reinforcement, and this can be an informative value) to which the stimulus led to in the past experience, or the importance of the interval (space, interruption) between the elements as a whole and interruption of the whole - for music, it is the end of the melody (places where the effect is information about the whole). Because the intervals between stimuli are more stimulant, just like all others. Precisely by not neglecting conditioning on intervals (temporal and spatial), the principles of grouping stimuli into wholes (touch, similarity, continuity, symmetry) are explained.

And the place of the strongest interruption of the elements (dynamic intensity of the stimulus) will be reacted to, that is, the place will not always and unconditionally follow the laws of movement towards a larger part (laws of the whole). A more molecular and shorter contact can be a stronger inhibitor, i.e. a factor 
in the formation of perception, than a more molar and longer continuity (also symmetry).

And why is the interruption of the whole such an important argument against the gestalt conception?

Because the interrupted whole- to which only one can react in a certain way - is still a limited stimulus (although we call it perception), and it, no matter how big, is only an element or stimulus (S) to which one reacts $(R)$, regardless of the fact that it itself is composed of smaller elements to which there is only no immediate reaction.

Thus, the gestalt notion of the whole is circular and tautological, because every stimulus, even the smallest one, has its parts (elements) and each perception, even the largest, is a part (element) of a larger perception. It is not true that the elements are not observed, they are only sometimes inhibited by a whole, and it can be the other way around. It depends on which level of stimulus we are aiming at, i.e. which part of the whole distracts $u s$, or, to put it more consistently: which stimulus is a component (V) of the strongest current effective potential (s Er).

Finally, it may be necessary to emphasize why the coordinate system was used in the display of melodies, and not the original and official, notation system: precisely because of the filtering of the external inhibition of the focus of the theme! Namely, due to the multitude of symbols that exist in the display of almost every melody (boosters, descents, flags, dots, dashes, intensity marks, etc.), there could be a confusion in the perception of similarities we are talking about here (for non-musicians for sure-and to whom thispaperis also dedicated): completely different melodies could be perceived as quite similar, thanks to these, secondary symbols (secondary to this paper). Only components that interest us (notes, intervals, tempo) are filtered out by the coordinate system.

The significance of this paper is, above all, theoretical because it proves that it is possible to connect two opposing great schools in science and psychology: behavioral and gestalt psychology. These are just different levels of analysis and different constructs. A set or assembly of smaller, elementary (molecular) stimuli gives a molar stimulus that causes the evocation of the main perceptual reaction, which is analogous to the law of perceptual organization in Gestalt psychology. Practically this kind of analysis and finding similarities in opposing attitudes and principles could be useful in other areas as well, such as pedagogical psychology and the development of creative thinking.

And finally, the art of listening can be improved by building up a positive reaction to listening and an active trying to eliminate communication murmurs (Cvetanovic, 2012).

\section{References}

Allport, F.H. (1955), Theories of perception and the concept of structure, N.Y., Wiley.

Boring, E.G. (1942), Sensation and perception in the history of experimental psychology, N.Y., Appleton-Century-Crofts.

Cvetanovic, I.(2012), IN FIERI, Niš, NKC.

Fajgelj, S. (2014), Uvod u psihologij. II, Beograd, CPP.

Hilgard, E.R. and Bower, G.H. (1975), Theories of learning, New Jersey, Prentice-Hall.

Hull, C. (1943), Principles of behavior, N.Y., Appleton, Century, Crofts.

Hull, C. (1952), A behavior system, New Haven, Yale University Press.

Jones, D. and Elcock, J. (2001), History and Theories of Psychology: A Critical Perspective, London: Arnold.

Kofka, K. (1935), Principles of Gestalt psychology, N.Y., Harcourt Brace. Liveright.

Kohler, W. (1929), Gestalt psychology, N.Y.,

Komlenić, M. (1997), "Humor kao perceptivno-kognitivni složaj reakcija“, Sabor Psihologa, Tara, DPS, Zbornik radova, 133-134.

Komlenić, M. (2003), "Non-repetition of reaction as the essence of reinforcement and motivation", 8th European Congress of psychology, 6-11 july 2003, Vienna, Austria, Apstract Book, 192.

Komlenić, M. (2011), "Reaktivna inhibicija: prediktor nedopadanja“, XVII Naučni skup Empirijska istraživanja u psihologiji, 11. i 12. februar 2011, Filozofski fakultet, Univerzitet u Beogradu, Knjiga rezimea, 52-54. 
Komlenić, M. (2013), Formula humora Učenje $i$ smešno, Filozofski fakultet: Niš.

Komlenić, M. (2014), "Odnos između maksima i aforizama", Nauka $i$ sloboda. Međunarodni naučni skup. 16-18. maj 2014. Pale: Filozofski fakultet u Istočnom Sarajevu.

Krech, D., Crutchfield, R. S., \& Livson, N. (1974), Elements of psychology (3rd ed.). Alfred A. Knopf.

Milićević, N. (2019), Empirijska istraživanja estetskog doživljaja. [Empirical Researches of Aesthetic Expirience], Filozofski fakultet. Niš: Unigraf - X - Copy. ISBN 978-86-7379-503-4.

Murphy, G. (1949), Historical introduction to modern psychology (Rev. ed.), Harcourt, Brace.

Nagge, J.W. (1935), "An experimental test of the theory of associative interference", J.exp.Psychol., 18, 663-82.

Ognjenović, P. (2002), Psihologija opažanja, Beograd: Zavod za izdavanje udžbenika.

Osgood, C.E. (1946), "Meaningful similarity and interference in learning", J.exp.Psychol., 36, 277-301.

Osgood, C.E. (1952), "The nature and measurement of meaning“, Psychol.Bull.,49, 197237.

Osgood, C.E. (1953), Method and Theory in Experimental Psychology, Oxford Univ. Press, New York.USA.

Radonjić, S. (1981), Uvod u psihologiju struktura psihologije kao nauke, Beograd, Zavod za udžbenike i nastavna sredstva.

Radonjić, S. (1985), Psihologija učenja I, Beograd, Zavod za udžbenike i nastavna sredstva.

Woodworth, R. S., \& Schlosberg, H. (1954), Experimental psychology (Rev. ed.). Holt.

$\begin{array}{cccc}\text { YU } & \text { Grupa, (1973), Crni } & \begin{array}{c}\text { leptir } \\ \text { [Black }\end{array} & \text { Butterfly }]\end{array}$
https://www.youtube.com/watch?v=Lm5WpIeSaU A (Accessed 19 December 2019).
Zlatko \& DAH, (1976), Shoshana (original Israel song).

$$
\text { https://www.youtube.com/watch?v=dlfxg5_C }
$$

T9Q (Accessed 19 May 2020). http://www.pesmarica.rs/Akordi/9030/Zlatko-

DAH-\%C5\%A0o\%C5\%A1ana (Accessed 19 May 2020).

Информация о конфликте интересов: авторы не имеют конфликта интересов для декларации.

Conflicts of Interest: the authors have no conflict of interests to declare.

\section{About the authors:}

Miroslav B. Komlenic, Doctor of Psychological Sciences, Assistant Professor, Faculty of Philosophy, State University of Nis, Serbia. ORCID: 00000002-4510-6955.

Nebojsa M. Milicevic, Doctor of Psychological Sciences, Professor, Faculty of Philosophy, State University of Nis, Serbia. ORCID: 0000-00033289-3088.

Miodrag B. Milenovic, Doctor of Psychological Sciences, Professor, Faculty of Philosophy, State University of Nis, Serbia. ORCID: 0000-00031984-0088.

\section{Данные авторов:}

Комленич Мирослав Б., доктор психологических наук, доцент, Философский факультет Университета в Нише, Республика Сербия. ORCID: 0000-0002-4510-6955.

Миличевич Небойша М., доктор психологических наук, профессор, Философский факультет Университета в Нише, Республика Сербия.ORCID:0000-0003-3289-3088.

Миленович Миодраг Б., доктор психологических наук, профессор, Философский факультет Университета в Нише, Республика Сербия. ORCID:0000-0003-1984-0088. 